\title{
The Infection Hypothesis of Schizophrenia: A Systematic Review
}

\author{
Alexander M. Scharko \\ Rogers Memorial Hospital, Milwaukee, USA \\ E-mail: ascharko@mcw.edu \\ Received February 19, 2011; revised March 25, 2011; accepted March 28, 2011
}

\begin{abstract}
Objectives: The objective of this paper is to accomplish a systematic review of the infection hypothesis of schizophrenia. Methods: All English language publications from January 1989 to March 2010 as related to infection and schizophrenia were obtained. Each study selected for analysis must either deal with the direct infection of an individual and schizophrenia or maternal infection during pregnancy and the subsequent development of schizophrenia in the offspring. The primary outcome measure was the calculated odds ratio and 95\% confidence interval (CI). Results: Over 300 titles and abstracts were reviewed. Eight retrospective studies regarding in utero exposure were analyzed. Five nested case-controlled studies yielded an overall odds ratio of 3.58 (95\% CI: 2.71 - 4.71) with a percent attributable risk of 6.3\%. Three Scandinavian populational studies yielded an overall odds ratio of 0.62 (95\% CI: 0.49 - 0.79). Twenty-six papers were identified as retrospective studies focused on linking evidence of past infection in individuals with history of schizophrenia. A total of 77 microorganisms were assessed with 18 (23.4\%) showing a positive association with schizophrenia. But positive associations in a given trial were negative in other trials. Conclusions: Direct infection of an individual as a cause of schizophrenia is unlikely. Results were mixed regarding maternal infection, in utero exposure, and the later development of schizophrenia in the offspring and likely accounts for a modest proportion of those with schizophrenia, possibly $6 \%$.
\end{abstract}

Keywords: Infection Hypothesis, Schizophrenia

\section{Introduction}

The idea that a microorganism may be involved in the pathophysiology of mental illness is not new. An editorial contained in an 1896 issue of Scientific American suggested that certain kinds of mental illness might be due to infection (Scientific American 1896; 75: 303). In 1908, Chicago surgeon Bayard Taylor Holmes, believing that focal infections, perhaps in the gastrointestinal tract, induces a state of autointoxication that in turn causes mental and physical illness, wrote, "It is my opinion that there are many cases of insanity which are due to exogenous toxemia that should be sought for in the infection of some of the natural cavities of the body..." [1,2]. The neurodevelopmental model of schizophrenia proposes that schizophrenia is the ultimate result of a perturbation in brain development that occurs long before the manifestation of frank symptoms and that schizophrenia is caused by a complex combination of genetic and environmental factors that are still poorly understood $[3,4]$. It is possible that a two-step mechanism involving (1) an internal genetic milieu that is permissive towards schizophrenia along with an (2) external environmental element(s) together provide the initial insult to neurodevelopment that pushes the individual to develop schizophrenia later in life. The environmental element in some instances could be infection.

Since the first part of the $20^{\text {th }}$ century, largely following advances in molecular biology methods, mental health researchers have attempted to identify microorganisms that might be involved in the pathophysiology of mental illness, specifically schizophrenia. Many microorganisms have been implicated (Table 1) including viruses, bacteria, and at least one protozoan [5-7]. This paper identifies, reviews, analyzes, and quantifies the research on the infection hypothesis of schizophrenia. A systematic review was performed. The results and conclusions are discussed in the framework of the neuro- 
Table 1. The infection hypothesis of schizophrenia - candidate microorganisms.

\begin{tabular}{|c|c|c|}
\hline Viruses & Bacteria & Protozoan \\
\hline Adenovirus 7 & Borrelia burgdorferi & Toxoplasma gondii \\
\hline Borna Disease Virus (BDV) & Chlamydia trachomatis & \\
\hline Bovine Viral Diarrhea Virus (BVDV) & Mycoplasma pneumoniae & \\
\hline \multicolumn{3}{|l|}{ Japanese Encephalitis Virus (JEV) } \\
\hline \multicolumn{3}{|l|}{ Cytomegalovirus (CMV) } \\
\hline \multicolumn{3}{|l|}{ Epstein-Barr Virus (EBV) } \\
\hline \multicolumn{3}{|l|}{ Herpes Simplex Virus-1 (HSV-1) } \\
\hline \multicolumn{3}{|l|}{ Herpes Simplex Virus-2 (HSV-2) } \\
\hline \multicolumn{3}{|l|}{ Human Herpes Virus-6 (HHV-6) } \\
\hline \multicolumn{3}{|l|}{ Varicella-Zoster Virus (VZV) } \\
\hline \multicolumn{3}{|l|}{ Influenza Virus } \\
\hline \multicolumn{3}{|l|}{ Measles Virus (Rubeola) } \\
\hline \multicolumn{3}{|l|}{ Mumps Virus } \\
\hline \multicolumn{3}{|l|}{ Human Parvovirus B19 } \\
\hline \multicolumn{3}{|l|}{ Coxsackie Virus B5 } \\
\hline \multicolumn{3}{|l|}{ Poliovirus } \\
\hline \multicolumn{3}{|l|}{ Reovirus } \\
\hline \multicolumn{3}{|l|}{ Human Immunodeficiency Virus (HIV) } \\
\hline Rubella Virus & & \\
\hline
\end{tabular}

developmental model of schizophrenia.

\section{Methods}

\subsection{Search Strategy}

All publications relevant to infection as it relates to schizophrenia were obtained according to standard guidelines [8]. The systematic review of the literature was restricted to English language sources from January 1989 to March 2010. The bottom limit of January 1989 was chosen because it coincided with the introduction and wide spread use of high quality polymerase chain reaction (PCR) technique that could reliably detect picomolar amounts of microorganism nucleic acid [9]. Electronic databases used were Cochrane Library, Medline, and PsycINFO. These online searches were augmented by hand reviewing the reference lists of identified papers. All available studies, reviews, and reports that mentioned some aspect of infection as it relates to schizophrenia were considered. Any microorganism mentioned as possibly being involved as causing schizophrenia was cataloged and listed in Table 1.

The Cochrane Library search used the keyword "schizophrenia." A primary search of Medline and PsycINFO used the keyword pairing of "schizophrenia" and "infection." A secondary search of Medline and Psy-
cINFO was done pairing the keyword "schizophrenia" with the specific microorganisms in Table 1.

\subsection{The Definition of Schizophrenia}

For the purpose of this review, the diagnosis of schizophrenia as defined by the authors of each study selected for analysis was accepted.

\subsection{Selection Criteria and Primary Outcome Measure}

In order to be included for analysis in this review, each study must satisfy the following two selection factors:

1) Focus of a selected study must be either on the direct infection of an individual and schizophrenia or maternal infection during pregnancy with subsequent development of schizophrenia in the offspring.

2) Each selected study must contain sufficient data to calculate an odds ratio.

The primary outcome measure is the calculated odds ratio along with the $95 \%$ confidence interval. The odds ratio was chosen because it is a statistic that estimates the relative risk in case-controlled studies[10], which was the study design anticipated to be encountered most frequently. The odds ratio and 95\% confidence interval (CI) were calculated according to the method described by 
Dawson and Trapp [10]. Studies yielding positive or negative results were included. Case reports and reviews were used to augment the search process, but not used for analysis. The search was not limited to any one specific microorganism.

\subsection{Addressing Missing Data}

For those studies that lent themselves to yielding an odds ratio, but data within the paper were either incomplete or absent, the principal investigator was contacted and asked for those appropriate data in order to calculate odds ratios.

\subsection{Data Extraction and Analysis}

Data from each study, review, and report were recorded on a data extraction form. Information abstracted included microorganism(s), study design, details regarding method, and results. Studies eligible for analysis were used to calculate an odds ratio. Homogeneity among studies was determined by the results of graphically plotting the proportion of those with schizophrenia onset in the infection-exposed groups on the vertical axis and the proportion of those with schizophrenia onset in the control groups on the horizontal axis. A linear trend was assumed to indicate good homogeneity. Where appropri- ate, numbers were combined to generate an overall odds ratio and $95 \%$ confidence interval. Where appropriate, the percent attributable risk, the percent of occurrence of the disorder in those individuals exposed that is due to the exposure, was then calculated [11].

\section{Results}

Over 300 titles and abstracts were reviewed. No prospective cohort studies were found with the specific aim of following into adulthood the children of mothers with documented infection during pregnancy and assessing psychiatric status. No studies were found demonstrating the development of schizophrenia in an individual subsequent to an episode of infection.

With respect to indirect evidence linking infection and schizophrenia, 13 papers were initially identified as being retrospective cohort studies focusing on maternal infection during pregnancy and the later development of schizophrenia in adult offspring [12-24]. All but two [17, 20] reported a positive association between infection and the development of schizophrenia in the adult offspring. Five studies were excluded because of missing data $[12,15,19,21,23]$. The analysis for the remaining eight studies is displayed in Table 2. A graphical assessment (Figure 1) revealed reasonable homogeneity amongst the first five nested case controlled studies. Thus those data

Table 2. Maternal infection, in utero exposure, and later development of schizophrenia in the offspring.

\begin{tabular}{|c|c|c|c|c|c|c|c|c|}
\hline Study & $\begin{array}{l}\text { Microorganism } \\
\text { or Medical } \\
\text { Condition Re- } \\
\text { lated to Infec- } \\
\text { tion }\end{array}$ & $\begin{array}{c}\text { Basis for } \\
\text { Infection } \\
\text { Diagnosis } \\
\text { During Preg- } \\
\text { nancy }\end{array}$ & $\begin{array}{l}\text { Number with } \\
\text { Schizophrenia } \\
\text { and Exposure }\end{array}$ & $\begin{array}{c}\text { Number } \\
\text { without } \\
\text { Schizophrenia } \\
\text { and Exposure }\end{array}$ & $\begin{array}{l}\text { Number with } \\
\text { Schizophrenia } \\
\text { and No Ex- } \\
\text { posure }\end{array}$ & $\begin{array}{c}\text { Number } \\
\text { without } \\
\text { Schizophrenia } \\
\text { and No Ex- } \\
\text { posure }\end{array}$ & $\begin{array}{l}\text { Odds } \\
\text { Ratio }\end{array}$ & $\begin{array}{c}95 \% \\
\text { Confi- } \\
\text { dence } \\
\text { Interval }\end{array}$ \\
\hline $\begin{array}{l}\text { Brown et al., } \\
2006 \text { [17] }\end{array}$ & HSV-1/HSV-2 & Serologically & 16 & 24 & 55 & 86 & 1.04 & $0.48-2.26$ \\
\hline $\begin{array}{l}\text { Brown et al., } \\
2005 \text { [16] }\end{array}$ & $\begin{array}{c}\text { Toxoplasma } \\
\text { gondii }\end{array}$ & Serologically & 18 & 22 & 45 & 101 & 1.84 & $0.85-3.98$ \\
\hline $\begin{array}{c}\text { Brown et al., } \\
2004 \text { [13] }\end{array}$ & Influenza virus & Serologically & 22 & 37 & 85 & 163 & 1.14 & $0.61-2.14$ \\
\hline $\begin{array}{c}\text { Brown et al., } \\
2000 \text { [18] }\end{array}$ & $\begin{array}{l}\text { Respiratory } \\
\text { infections }\end{array}$ & Clinically & 9 & 623 & 49 & 7,100 & 2.09 & $0.96-4.44$ \\
\hline $\begin{array}{l}\text { Brown et al., } \\
2000 \text { [14] }\end{array}$ & Rubella virus & Clinically & 11 & 59 & $15^{*}$ & 1,511 & 18.78 & $7.67-45.66$ \\
\hline $\begin{array}{c}\text { Clarke et al., } \\
2009 \text { [20] }\end{array}$ & Pyelonephritis & $\begin{array}{c}\text { Finnish } \\
\text { Medical Reg- } \\
\text { istry }\end{array}$ & 36 & 9,560 & 35 & 13,773 & 1.48 & $0.908-2.419$ \\
\hline $\begin{array}{c}\text { Mortensen } \\
\text { et al., } 2007 \\
\text { [22] }\end{array}$ & $\begin{array}{l}\text { Toxoplasma } \\
\text { gondii }\end{array}$ & $\begin{array}{c}\text { Danish Medi- } \\
\text { cal Registry \& } \\
\text { Biobank }\end{array}$ & 17 & 68 & 54 & 616 & 2.85 & $1.50-5.39$ \\
\hline $\begin{array}{c}\text { Sorensen } \\
\text { et al., } 2009 \\
\text { [24] }\end{array}$ & $\begin{array}{l}\text { Bacterial } \\
\text { Infection }\end{array}$ & $\begin{array}{c}\text { Copenhagen } \\
\text { Perinatal } \\
\text { Cohort }\end{array}$ & 38 & 1,027 & 200 & 6,675 & 1.24 & $0.85-1.78$ \\
\hline $\begin{array}{l}\text { Combining } \\
\text { First Five } \\
\text { Studies }\end{array}$ & & & 76 & 765 & 249 & 8,961 & 3.58 & $2.71-4.71$ \\
\hline $\begin{array}{l}\text { Combining } \\
\text { Population } \\
\text { Studies }\end{array}$ & & & 91 & 10,655 & 289 & 21,064 & 0.62 & $0.49-0.79$ \\
\hline
\end{tabular}

* The number with schizophrenia and with no in utero exposure was estimated. Assuming a $1 \%$ prevalence of schizophrenia, then $1,511 \times 0.01 \approx 15$. 


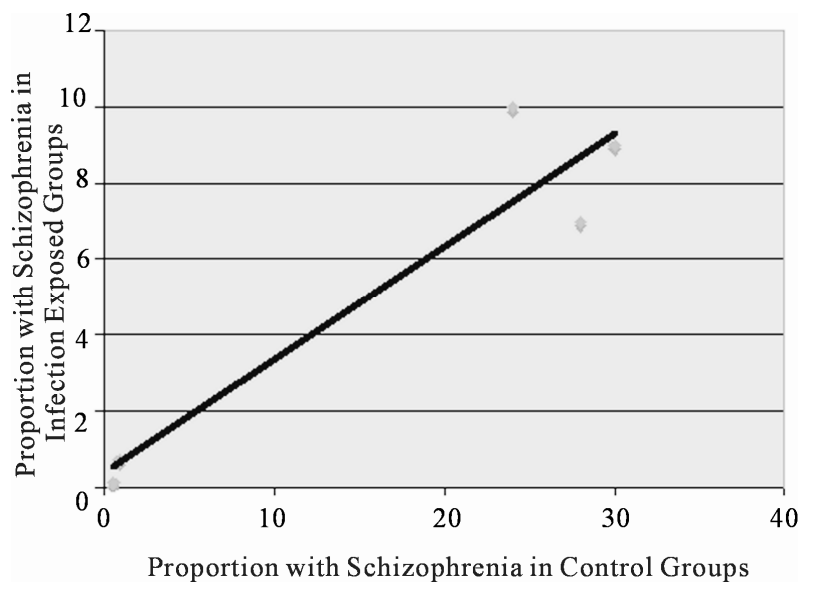

Figure 1. Heterogenity determination.

from the first five studies were pooled. The overall odds ratio from the first five studies showed an increased likelihood of schizophrenia among those exposed to maternal infection while in utero (Overall Odds Ratio $=3.58$; 95\% CI: 2.71 - 4.71) with a percent attributable risk of $6.3 \%$. Given the use of Scandinavian national databases, the population studies were assumed to be homogeneous and were combined. The three population studies yielded an overall odds ratio that suggested no increased likelihood of schizophrenia among those exposed to maternal infection while in utero (Overall Odds Ratio $=0.62 ; 95 \%$ CI: 0.49 - 0.79).

Another 26 published retrospective cohort studies attempted to link evidence of past infection with schizophrenia [25-50] (i.e., direct exposure to infection). Sam- ples ranged from post-mortem brain tissue to blood from patients and controls. Standard molecular biology techniques were used such as enzyme linked immunosorbent assay (ELISA), Western blot, and polymerase chain reaction (PCR). Frequently, multiple microorganisms were assessed in a given study. Taking each microorganism investigated as a separate trial, $23.4 \%$ of trials yielded a positive association (18 out of 77 trials; Table 3).

The 18 separate trials were published in 16 papers [27, 28,31,32,34-39,41-43,47,49,50]. Five trials from four papers were excluded because of missing data [27,36, 39,42]. Two positive trials focusing on other issues instead of infection causing schizophrenia were also excluded [31,32]. Eleven trials were included in the analysis (Table 4). A graphical assessment (Figure 2) revealed poor homogeneity amongst these 11 trials. Thus individual odds ratios were calculated for each of the 11 eligible trials and presented in Table 4. No overall odds ratio was calculated because homogeneity could not be assumed. One of those 11 trials contained zero in the odds ratio calculation [35], but still was listed in Table 4. Two separate studies seemed to use identical data [36,37].

Five studies were found that specifically investigated CNS infection occurring during childhood and the later development of schizophrenia [51-55]. Although all five studies showed a positive association between childhood CNS infection and the later development of schizophrenia, the possibility of infection-induced brain damage resulting in schizophrenia-like psychiatric symptoms could not be ruled out. Thus, these studies were not included for analysis.

Table 3. Evidence of past infection and history of schizophrenia - microorganisms investigated and outcome (77 total trials).

\begin{tabular}{ccc}
\hline Microorganism & $\begin{array}{c}\text { Number of Positive Associations } \\
\text { with Schizophrenia }\end{array}$ & $\begin{array}{c}\text { Number of Negative Associations } \\
\text { with Schizophrenia }\end{array}$ \\
\hline Borna Disease Virus (BDV) & $7(9.1 \%)$ & $3(3.9 \%)$ \\
Bovine Viral Diarrhea Virus (BVDV) & 0 & $1(1.3 \%)$ \\
Japanese Encephalitis Virus (JEV) & 0 & $1(1.3 \%)$ \\
Cytomegalovirus (CMV) & $2(2.6 \%)$ & $8(10.4 \%)$ \\
Epstein-Barr Virus (EBV) & 0 & $8(10.4 \%)$ \\
Herpes Simplex Virus-1 (HSV-1) & $1(1.3 \%)$ & $6(7.8 \%)$ \\
Herpes Simplex Virus-2 (HSV-2) & 0 & $5(6.5 \%)$ \\
Human Herpes Virus-6 (HHV-6) & $1(1.3 \%)$ & $6(7.8 \%)$ \\
Varicella-Zoster Virus (VZV) & 0 & $8(10.4 \%)$ \\
Influenza Virus & 0 & $5(6.5 \%)$ \\
Measles Virus (Rubeola) & 0 & $2(2.6 \%)$ \\
Mumps Virus & 0 & $2(2.6 \%)$ \\
Retrovirus & $2(2.6 \%)$ & $1(1.3 \%)$ \\
Rubella Virus & 0 & $1(1.3 \%)$ \\
Toxoplasma gondii & 0 & $1(1.3 \%)$ \\
Tuman Immunodeficiency Virus (HIV) & $5(6.5 \%)$ & $1(1.3 \%)$
\end{tabular}


Table 4. History of direct infection in individuals and the development of schizophrenia*.

\begin{tabular}{|c|c|c|c|c|c|c|c|}
\hline Study & $\begin{array}{l}\text { Microor- } \\
\text { ganism }\end{array}$ & $\begin{array}{l}\text { Number with } \\
\text { Schizophrenia } \\
\text { and Exposure }\end{array}$ & $\begin{array}{l}\text { Number without } \\
\text { Schizophrenia } \\
\text { and Exposure }\end{array}$ & $\begin{array}{c}\text { Number with } \\
\text { Schizophrenia } \\
\text { and No Exposure }\end{array}$ & $\begin{array}{l}\text { Number without } \\
\text { Schizophrenia } \\
\text { and No Exposure }\end{array}$ & $\begin{array}{l}\text { Odds } \\
\text { Ratio }\end{array}$ & $\begin{array}{l}\text { 95\% Confidence } \\
\text { Interval }\end{array}$ \\
\hline $\begin{array}{c}\text { Nunes et al., } \\
2008 \text { [43] }\end{array}$ & BDV & 12 & 4 & 15 & 23 & 4.60 & $1.08-21.09$ \\
\hline $\begin{array}{c}\text { Chen et al., } \\
1999 \text { [28] }\end{array}$ & BDV & 38 & 32 & 276 & 459 & 1.97 & $1.17-3.33$ \\
\hline $\begin{array}{l}\text { Iwahashi } \\
\text { et al., } \\
1998 \text { [37] }\end{array}$ & BDV & 30 & 1 & 37 & 30 & 24.32 & $3.21-513.30$ \\
\hline $\begin{array}{l}\text { Iwahashi } \\
\text { et al., } \\
1998 \text { [36] }\end{array}$ & BDV & 30 & 1 & 37 & 30 & 24.32 & 3.21 - 513.30 \\
\hline $\begin{array}{l}\text { Iwahashi } \\
\text { et al., } \\
1997 \text { [35] }\end{array}$ & BDV & 30 & 0 & 37 & 26 & NA & NA \\
\hline $\begin{array}{l}\text { Hart et al., } \\
1999 \text { [34] }\end{array}$ & Retrovirus & 29 & 4 & 38 & 12 & 2.29 & $0.60-9.46$ \\
\hline $\begin{array}{l}\text { Lillehoj et al., } \\
2000 \text { [40] }\end{array}$ & Retrovirus & 11 & 1 & 27 & 26 & 10.60 & $1.24-238.79$ \\
\hline $\begin{array}{l}\text { Niebuhr } \\
\text { et al., } \\
2008 \text { [41] }\end{array}$ & $\begin{array}{c}\text { Toxoplasma } \\
\text { gondii }\end{array}$ & 15 & 37 & 165 & 491 & 1.21 & $0.62-2.34$ \\
\hline $\begin{array}{c}\text { Tamer et al., } \\
2008 \text { [47] }\end{array}$ & $\begin{array}{c}\text { Toxoplasma } \\
\text { gondii }\end{array}$ & 16 & 6 & 24 & 31 & 3.44 & $1.05-11.73$ \\
\hline $\begin{array}{l}\text { Yolken } \\
\text { et al., } \\
2001[50]\end{array}$ & $\begin{array}{c}\text { Toxoplasma } \\
\text { gondii }\end{array}$ & 14 & 3 & 24 & 24 & 4.67 & $1.05-23.04$ \\
\hline
\end{tabular}

* BDV = Borna Disease Virus, NA = Not Applicable.

\section{Discussion}

Edwin Goodall, a President of the Section of Psychiatry in the British Royal Society of Medicine, lecturing in

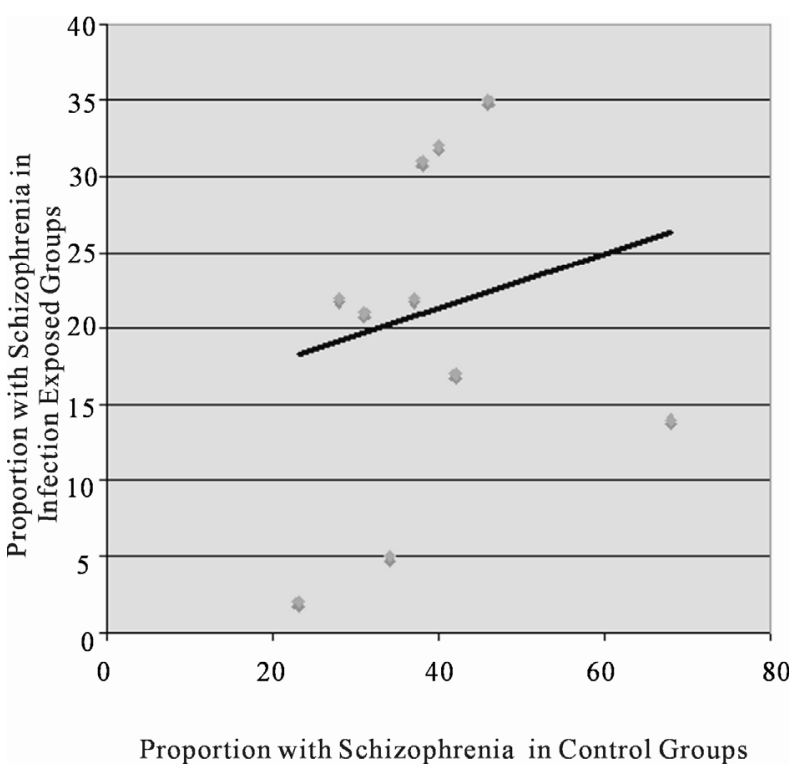

Figure 2. Heterogenity determination.
1932, stated, “...there is no essential difference connected with encephalitis (post-encephalitic) and those met within states covered by the description schizophrenia” [56]. Goodall went on to speculate, “...that a virus or toxin is the causative factor...vaccina, varicella, variola, measles, perhaps influenza.” Following Goodall's lead, it was later observed that there appears to be a $5 \%$ to $8 \%$ excess of late winter and early spring births of individuals who later in life develop schizophrenia [57]. This season-of-birth effect implied that maternal infection during pregnancy might be a factor in causing schizophrenia in the offspring. Further, data extrapolated from the analysis of ecological events, mostly the influenza pandemics, have linked prenatal exposures to infectious agents to the risk of developing schizophrenia later in life [58-69], although not all of those ecological studies showed a positive association [70-75]. In a review of prenatal infection and schizophrenia published in March 2010 Brown and Derkits [76] contend that of those individuals with schizophrenia perhaps as many as $30 \%$ could have been prevented if certain infections could have been avoided among pregnant women. The idea that infection is involved in the pathophysiology of schizophrenia simply will not go away. 
Although direct infection of an individual can produce psychiatric symptoms that look like schizophrenia $[77,78]$, three findings in this review argue against direct infection and the subsequent development of schizophrenia. First, as indicated in Table 3, there was essentially no consistency across studies as $76.6 \%$ of the possible associations were negative. Further, those microorganisms that produced positive associations in some trials also produced negative associations in other trials. Second, appropriate temporal sequencing was a concern because it was unclear precisely when infection occurred with respect to the onset of schizophrenia. It is known that about $75 \%$ of those individuals with schizophrenia also have a co-occurring physical health problem such as heart disease, cancer, or diabetes [79]. It then would not be unusual to find evidence of past infection by a variety of microorganisms in this population. Third, of those studies in which an odds ratio could be derived (Table 4), three contained one in the 95\% confidence interval calculation. Another three had exceedingly wide confidence intervals. These statistical results call into question whether a true association actually exists. Finally, it is more biologically plausible that schizophrenia is a neurodevelopmental disorder and not the sequela of acute infection. An infection process that precipitates psychotic symptoms is better characterized as delirium or psychosis due to a medical condition as opposed to schizophrenia. Taken together, these findings suggest it is unlikely that direct infection of an individual is a cause of schizophrenia.

Table 2 shows mixed evidence regarding maternal infection during pregnancy and the later development of schizophrenia in the offspring. The first five studies are unique in that each study was a nested case controlled design that drew upon well-defined populations and each of the five studies were done by the same research group. Overall, the findings suggested a 3.58 (95\% CI: 2.71 4.71) greater risk of later development of schizophrenia in offspring with in utero exposure to a microorganism, and/or the products and consequences of infection, than in those without such exposure. This in utero effect may account for up to $6 \%$ of cases of schizophrenia. These results stand in contrast to the three Scandinavian populational studies that actually indicate a protective effect with respect to maternal infection with an overall odds ratio of 0.62 (95\% CI: $0.49-0.79)$. If those data across all of the studies in Table 2 were combined the odds ratio becomes 0.82 with a $95 \%$ confidence interval of 0.68 to 0.98 ; perilously close to one and implying that maternal infection is not a major cause of schizophrenia in the offspring.

Microorganisms and humans evolved together. It is no surprise that there exists many connections, overlaps, and interactions between microorganisms and human physicological chemistry [80]. One might consider evoking the hygiene hypothesis [81] and say that a certain amount of maternal infection or microbial colonization is tolerated, perhaps even required, during pregnancy. But, it may be that once a critical inflection point is reached with respect to microbial involvement, fetal and/or maternal tolerances may be breached thus placing the developing fetal nervous system at some degree of risk. An explanation that fits with the neurodevelopmental model of schizophrenia is that microbial gene products that mimic host cytokines (such as virokines [82,83] or other pseudo-cytokines from bacteria or protozoans) and/or the generation of pro-inflammatory cytokines [84,85] may perturb fetal neurodevelopment in a subtle, but significant way that later results in the development of schizophrenia. At what neuro-location within the fetus and at what moment of development is most vulnerable are unknown, but stochastic factors are likely involved. Unfortunately, nothing was said about the fathers of those offspring who later went on to develop schizophrenia. There is reason to believe that older paternal age is a risk factor for the later development of schizophrenia in the offspring [86]. Paternal age then was a possible confounding factor in those studies focusing on maternal infection. Finally, none of the studies surveyed for this review could account for the lack of increase in prevalence of schizophrenia in those areas of the world where infectious disease is prominent [87]. There is evidence that schizophrenia is more prevalent in the developed countries where one would think that public health measures and infection control would be the best[88]. Thus, in utero exposure to a microorganism, and/or the products or consequences of infection, as a cause of schizophrenia - although a good example of gene/environment interaction $[80,89]$ and consistent with the neurodevelopmental model of schizophrenia - may only account for a modest proportion of those individuals with schizophrenia, perhaps 6\%.

This systematic review has several limitations. First, it only contained studies that were published after January 1989. Unpublished reports and studies in languages other than English were not collected. Thus not every study regarding infection and schizophrenia was evaluated in the formal analysis. Second, the problem of missing data was difficult to overcome. Therefore several studies needed to be excluded from formal analysis. Third, homogeneity was a major problem for those studies attempting to relate direct infection in an individual and the subsequent development of schizophrenia (Table 4). This precluded combining odds ratio data in any straightforward way. Fourth, the definition of schizophrenia varied from study to study. It frequently was 
difficult to differentiate a valid diagnosis of schizophrenia from a medical condition manifesting with schizophrenia-like symptoms, such as delirium or psychosis due to a medical condition.

\section{Acknowledgements}

Susan dosReis, PhD Assistant Professor, Division of Child and Adolescent Psychiatry, Johns Hopkins University School of Medicine, Baltimore, MD, provided valuable comments and statistical consultation. David C. Lee, PhD, JD, Director of Psychology and Research, Mendota Mental Health Institute, Madison, WI, kindly edited an earlier version of this review.

\section{References}

[1] R. Noll, "Infectious Insanities, Surgical Solutions: Bayard Taylor Holmes, Dementia Praecox and Laboratory Science in Early 20th-Century America. Part 1," History of Psychiatry, Vol. 17, No. 2, 2006, pp. 183-204. doi:10.1177/0957154X06059456

[2] R. Noll, "Infectious Insanities, Surgical Solutions: Bayard Taylor Holmes, Dementia Praecox and Laboratory Science in Early 20th-Century America. Part 2," History of Psychiatry, Vol. 17, No. 2, 2006, pp. 299-311. doi:10.1177/0957154X06059446

[3] D. Lewis and P. Levitt, "Schizophrenia as a disorder of neurodevelopment," Annual Review of Neuroscience, Vol. 25, No. 2, 2002, pp. 409-432. doi:10.1146/annurev.neuro.25.112701.142754

[4] J. Rapoport, A. Addington and S. Frangou S, "The Neurodevelopmental Model of Schizophrenia: Update 2005,” Molecular Psychiatry, Vol. 10, No. 5, 2005, pp. 434-449.

[5] A. Brown and E. Susser, "In Utero Infection and Adult Schizophrenia,” Mental Retardation and Developmental Disabilities Research Reviews, Vol. 8, No. 1, 2002, pp. 51-57. doi:10.1002/mrdd.10004

[6] M. Debnath and T. Chaudhuri, "The Role of HLA-G in Cytokine Homeostasis during Early Pregnancy Complicated with Maternal Infections: A Novel Etiopathological Approach to the Neurodevelopmental Understanding of Schizophrenia," Medical Hypotheses, Vol. 66, No. 2, 2006, pp. 286-293.

[7] R. Yolken and E. Torrey, "Are Some Cases of Psychosis Caused by Microbial Agents? A Review of the Evidence," Molecular Psychiatry, Vol. 13, No. 5, 2008, pp. 470-479.

[8] M. Egger and G. D. Smith, "Principles of and Procedures for Systematic Reviews,” In: M. Egger, G. D. Smith and D. G. Altman, Eds., Systematic Reviews in Health Care: Meta-analysis in Context, British Medical Journal, London, 2001, pp. 23-42. doi:10.1002/9780470693926.ch2

[9] K. Mullis, "The Unusual Origin of the Polymerase Chain Reaction,” Scientific American, Vol. 262, No. 4, 1990, pp. 56-65. doi:10.1038/scientificamerican0490-56
[10] B. Dawson and R. Trapp, "Basic \& Clinical Biostatistics," Lange Medical Books/McGraw-Hill, New York, 2001.

[11] C. Hennekens and S. Maynert, "Epidemiology in Medicine,” Lippincott Williams \& Wilkins, Philadelphia, 1987.

[12] V. Babulas, P. Factor-Litvak, R. Goetz, C. Schaefer and A. Brown, "Prenatal Exposure to Maternal Genital and Reproductive Infections and Adult Schizophrenia," American Journal of Psychiatry, Vol. 163, No. 5, 2006, pp. 927-929. doi:10.1176/appi.ajp.163.5.927

[13] A. Brown, M. Begg, S. Gravenstein, C. Schaefer, R. Wyatt, M. Bresnahan, V. Babulas and E. Susser, "Serological Evidence of Prenatal Influenza in the Etiology of Schizophrenia,” Archives of General Psychiatry, Vol. 61, No. 8, 2004, pp. 774-780. doi:10.1001/archpsyc.61.8.774

[14] A. Brown, P. Cohen, S. Greenwald and E. Susser, "Nonaffective Psychosis after Prenatal Exposure to Rubella," American Journal of Psychiatry, Vol. 157, No. 3, 2000, pp. 438-443.

[15] A. Brown, P. Cohen, J. Harkavy-Friedman, V. Babulas, D. Malaspina, J. Gorman and E. Susser, "Prenatal Rubella, Premorbid Abnormalities, and Adult Schizophrenia,” Biological Psychiatry, Vol. 49, No. 6, 2001, pp. 473-486. doi:10.1016/S0006-3223(01)01068-X

[16] A. Brown, C. Schaefer, C. Quesenberry, V. Babulas and E. Susser, "Maternal Exposure to Toxoplasmosis and Risk of Schizophrenia in Adult Offspring," American Journal of Psychiatry, Vol. 162, No. 4, 2005, pp. 767-773.

[17] A. Brown, C. Schaefer, C. Quesenberry, L. Shen and E. Susser, "No Evidence of Relation between Maternal Exposure to Herpes Simplex Virus Type 2 and Risk of Schizophrenia," American Journal of Psychiatry, Vol. 163, No. 12, 2006, pp. 2178-2180. doi:10.1176/appi.ajp.163.12.2178

[18] A. Brown, C. Schaefer, R. Wyatt, R. Goetz, M. Begg, J. Gorman and E. Susser, "Maternal Exposure to Respiratory Infections and Adult Schizophrenia Spectrum Disorders: A Prospective Birth Cohort Study," Schizophrenia Bulletin, Vol. 26, No. 2, 2000, pp. 287-295.

[19] S. Buka, M. Tsuang, E. Torrey, M. Klebanoff, D. Bernstein and R. Yolken, "Maternal Infections and Subsequent Psychosis among Offspring," Archives of General Psychiatry, Vol. 58, No. 11, 2001, pp. 1032-1037. doi:10.1001/archpsyc.58.11.1032

[20] M. Clarke, A. Tanskanen, M. Huttunen, J. Whittaker and M. Cannon, "Evidence for an Interaction between Familial Liability and Prenatal Exposure to Infection in the Causation of Schizophrenia," American Journal of Psychiatry, Vol. 166, No. 9, 2009, pp. 1025-1030.

[21] S. Mednick, M. Huttunen and R. Machon, "Prenatal Influenza Infections and Adult Schizophrenia," Schizophrenia Bulletin, Vol. 20, No. 2, 1994, pp. 263-267.

[22] P. Mortensen, B. Norgaard-Pedersen, B. Waltoft, T. Sorensen, D. Hougaard, E. Torrey and R. Yolken, “Toxoplasma Gondii as a Risk Factor for Early-onset 
Schizophrenia: Analysis of Filter Paper Blood Samples Obtained at Birth,” Biological Psychiatry, Vol. 61, No. 5, 2007, pp. 688-693.

[23] P. Sham, C. MacClean and K. Kendler, "Risk of Schizophrenia and Age Differences with Older Siblings," The British Journal of Psychiatry, Vol. 163, 1993, pp. 627-633. doi:10.1192/bjp.163.5.627

[24] H. Sorensen, E. Mortensen, J. Reinisch and S. Mednick, "Association between Prenatal Exposure to Bacterial Infection and Risk of Schizophrenia,” Schizophrenia Bulletin, Vol. 35, No. 3, 2009, pp. 631-637. doi:10.1093/schbul/sbn121

[25] R. Alexander, G. Cabirac, T. Lowenkopf, M. Casanova, J. Kleinman, R. Wyatt and D. Kirch, "Search for Evidence of Herpes Simplex Virus, Type 1, or Varicella-zoster Virus Infection in Postmortem Brain Tissue from Schizophrenic Patients," Acta Psychiatrica Scandinavica, Vol. 86, 1992, pp. 418-420.

[26] R. Alexander, S. Spector, M. Casanova, J. Kleinman, R. Wyatt and D. Kirch, "Search for Cytomegalovirus in the Postmortem Brains of Schizophrenic Patients Using the Polymerase Chain Reaction," Archives of General Psychiatry, Vol. 49, No. 1, 1992, pp. 47-53.

[27] S. Bachmann, J. Schroder, C. Bottmer, E. Torrey and R. Yolken, "Psychopathology in First-Episode Schizophrenia and Antibodies to Toxoplasma Gondii," Psychopathology, Vol. 38, No. 2, 2005, pp. 87-90. doi:10.1159/000085349

[28] C. H. Chen, Y. L. Chiu, F. C. Wei, F. J. Koong, H. C. Liu, C. K. Shaw, H. G. Hwu and K. J. Hsiao, "High Seroprevalence of Borna Virus Infection in Schizophrenic Patients, Family Members and Mental Health Workers in Taiwan,” Molecular Psychiatry, Vol. 4, No. 1, 1999, pp. 33-38.

[29] M. Coggiano, R. Alexander, D. Kirch, R. Wyatt and H. Kulaga, "The Continued Search for Evidence of Retroviral Infection in Schizophrenic Patients," Schizophrenia Research, Vol. 5, 1991, pp. 243-247. doi:10.1016/0920-9964(91)90082-3

[30] C. Conejero-Goldberg, E. Torrey and R. Yolken, "Herpesviruses and Toxoplasma Gondii in Orbital Frontal Cortex of Psychiatric Patients," Schizophrenia Research, Vol. 60, 2003, pp. 65-69. doi:10.1016/S0920-9964(02)00160-3

[31] F. Dickerson, J. Boronow, C. Stallings, A. Origoni, I. Ruslanova and R. Yolken, "Association of Serum Antibodies to Herpes Simplex Virus 1 with Cognitive Deficits in Individuals with Schizophrenia,” Archives of General Psychiatry, Vol. 60, No. 5, 2003, pp. 466-472. doi:10.1001/archpsyc.60.5.466

[32] F. Dickerson, B. Kirkpatrick, J. Boronow, C. Stallings, A. Origoni and R. Yolken, "Deficit Schizophrenia: Association with Serum Antibodies to Cytomegalovirus,” Schizophrenia Bulletin, Vol. 32, No. 2, 2006, pp. 396-400. doi:10.1093/schbul/sbi054

[33] R. Fukuda, T. Sasaki, H. Kunugi and S. Nanko, "No Changes in Paired Viral Antibody Titers during the Course of Acute Schizophrenia," Neuropsychobiology, Vol. 40, No. 2, 1999, pp. 57-62.
[34] D. Hart, R. Heath, F. Sautter, B. Schwartz, R. Grarry, B. Choi, M. Beilke and L. Hart, “Antiretroviral Antibodies: Implications for Schizophrenia, Schizophrenia Spectrum Disorders, and Bipolar Disorder,” Biological Psychiatry, Vol. 45, No. 6, 1999, pp. 704-714. doi:10.1016/S0006-3223(98)00229-7

[35] K. Iwahashi, M. Watanabe, K. Nakamura, H. Suwaki, T. Nakaya, Y. Nakamura, H. Takahashi and K. Ikuta, "Clinical Investigation of the Relationship between Borna Disease Virus (BDV) Infection and Schizophrenia in 67 Patients in Japan,” Acta Psychiatrica Scandinavica, Vol. 96, 1997, pp. 412-415. doi:10.1111/j.1600-0447.1997.tb09941.x

[36] K. Iwahashi, M. Watanabe, K. Nakamura, H. Suwaki, T. Nakaya, Y. Nakamura, H. Takahashi and K. Ikuta, "Borna Disease Virus Infection and Schizophrenia: Seroprevalence in Schizophrenic Patients,” Canadian Journal of Psychiatry, Vol. 43, No. 2, 1998, p. 197.

[37] K. Iwahashi, M. Watanabe, K. Nakamura, H. Suwaki, T. Nakaya, Y. Nakamura, H. Takahashi and K. Ikuta, "Borna Disease Virus Infection and Negative Syndromes in Japanese Schizophrenia Patients," Psychiatry and Clinical Neurosciences, Vol. 52, No. 1, 1998, p. 119. doi:10.1111/j.1440-1819.1998.tb00984.x

[38] K. Iwahashi, M. Watanabe, K. Nakamura, H. Suwaki, T. Nakaya, Y. Nakamura, H. Takahashi and K. Ikuta, "Positive and Negative Syndromes, and Borna Disease Virus Infection in Schizophrenia," Neuropsychobiology, Vol. 37, No. 2, 1998, pp. 59-64.

[39] F. Leweke, C. Gerth, D. Koethe, J. Klosterkotter, I. Ruslanova, B. Krivogorsky, E. Torrey and R. Yolken, "Antibodies to Infectious Agents in Individuals with Recent Onset Schizophrenia,” European Archives of Psychiatry and Clinical Neuroscience, Vol. 254, No. 1, 2004 pp. 4-8. doi:10.1007/s00406-004-0481-6

[40] E. Lillehoj, G. Ford, S. Bachmann, J. Schroder, E. Torrey and R. Yolken, "Serum Antibodies Reactive with Non-human Primate Retroviruses Identified in Acute Onset Schizophrenia,” Journal of Neurovirology, Vol. 6, 2000, pp. 492-497. doi:10.3109/13550280009091949

[41] D. Niebuhr, A. Millikan, D. Cowan, R. Yolken, Y. Li and N. Weber, "Selected Infectious Agents and Risk of Schizophrenia among US Military Personnel,” American Journal of Psychiatry, Vol. 165, No. 1, 2008, pp. 99-106. doi:10.1176/appi.ajp.2007.06081254

[42] D. Niebuhr, A. Millikan, R. Yolken, Y. Li and N. Weber, "Results from a Hypothesis Generating Case-Controlled Study: Herpes Family Viruses and Schizophrenia among Military Personnel," Schizophrenia Bulletin, Vol. 34, No. 6, 2008, pp. 1182-1188. doi:10.1093/schbul/sbm139

[43] S. Nunes, E. Itano, M. Amarante, E. Reiche, H. Miranda, C. de Oliveira, T. Matsuo, H. Vargas and M. Watanabe, "RNA from Borna Disease Virus in Patients with Schizophrenia, Schizoaffective Patients, and in Their Biological Relatives,” Journal of Clinical Laboratory Analysis, Vol. 22, No. 4, 2008, pp. 314-320. doi:10.1002/jcla.20261

[44] A. Pelonero, A. Pandurangi and V. Calabrese, "Serum IgG Antibody to Herpes Viruses in Schizophrenia,” Psy- 
chiatry Research, Vol. 33, No. 1, 1990, pp. 11-17. doi:10.1016/0165-1781(90)90144-T

[45] J. Richt, R. Alexander, S. Herzog, D. Hooper, R. Kean, S. Spitsin, K. Bechter, R. Schuttler, H. Feldmann, A. Heiske, Z. Fu, B. Dietzschyold, R. Rott and H. Koprowski, "Failure to Detect Borna Disease Virus Infection in Peripheral Blood Leukocytes from Humans with Psychiatric Disorders," Journal of Neurovirology, Vol. 3, 1997, pp. 174-178. doi:10.3109/13550289709015807

[46] A. Sierra-Honigmann, K. Carbone and R. Yolken, "Polymerase Chain Reaction (PCR) Search for Viral Nucleic Acid Sequences in Schizophrenia," British Journal of Psychiatry, Vol. 166, No. 1, 1995, pp. 55-60. doi:10.1192/bjp.166.1.55

[47] G. Tamer, D. Dundar, I. Yalug, S. Caliskan, S. Yazar and A. Aker, "The Schizophreina and Toxoplasma Gondii Connection: Infectious, Immune or Both?” Advances in Therapy, Vol. 25, No. 7, 2008, pp. 703-709.

[48] H. Terayama, Y. Nishino, M. Kishi, K. Ikuta, M. Itoh and K. Iwahashi, "Detection of Anti-Borna Disease Virus (BDV) Antibodies from Patients with Schizophrenia and Mood Disorders in Japan,” Psychiatry Research, Vol. 120, No. 2, 2003, pp. 201-206.

[49] R. Waltrip II, R. Buchanan, A. Summerfelt, A. Breier, W. Carpenter, N. Bryant, S. Rubin and K. Carbone, "Borna Disease Virus and Schizophrenia,” Psychiatry Research, Vol. 56, No. 1, 1995, pp. 33-44. doi:10.1016/0165-1781(94)02600-N

[50] R. Yolken, S. Bachmann, I. Rouslanova, E. Lillehoj, G. Ford, E. Torrey and J. Schroeder, “Antibodies to Toxoplasma Gondii in Individuals with First-Episode Schizophrenia,” Clinical Infectious Diseases, Vol. 32, No. 5, 2001, pp. 842-844. doi:10.1086/319221

[51] C. Dalman, P. Allebeck, D. Gunnell, G. Harrison, K. Kristensson, G. Lewis, S. Lofving, F. Rasmussen, S. Wicks and H. Karlsson, "Infections in the CNS during Childhood and the Risk of Subsequent Psychotic Illness: A Cohort Study of More than One Million Swedish Subjects," American Journal of Psychiatry, Vol. 165, No. 1, 2008, pp. 59-65. doi:10.1176/appi.ajp.2007.07050740

[52] H. Koponen, P. Rantakallio, J. Veijola, P. Jones, J. Jokelainen and M. Isohanni, "Childhood Central Nervous System Infections and Risk for Schizophrenia,” European Archives of Psychiatry and Clinical Neurosciences, Vol. 254, 2004, pp. 9-13.

[53] S. Leask, D. Done and T. Crow, “Adult Psychosis, Common Childhood Infections and Neurological Soft Signs in a National Birth Cohort,” British Journal Psychiatry, Vol. 181, No. 5, 2002, pp. 387-392. doi:10.1192/bjp.181.5.387

[54] P. Rantakallio, P. Jones, J. Moring and L. von Wendt, "Association between Central Nervous System Infections during Childhood and Adult Onset Schizophrenia and Other Psychosis: A 28-Year Follow-Up,” International Journal of Epidemiology, Vol. 26, No. 4, 1997, pp. 837-843. doi:10.1093/ije/26.4.837

[55] J. Veijola, P. Jones, T. Makikyro, J. Moring, P. Rantakallio and M. Isohanni, "Early Associations of Schizophrenia in the 1966 North Finland General Population Birth
Cohort,” International Journal of Mental Health, Vol. 29, 2001, pp. 84-90.

[56] E. Goodall, “The Exciting Cause of Certain States, at Present Classified under Schizophrenia by Psychiatrists, may be Infection," Journal of Mental Science, Vol. 78, 1932, pp. 746-755.

[57] E. Torrey, J. Miller, R. Rawlings and R. Yolken, "Seasonality of Births in Schizophrenia and Bipolar Disorder: A Review of the Literature," Schizophrenia Research, Vol. 28, No. 1, 1997, pp. 1-38. doi:10.1016/S0920-9964(97)00092-3

[58] W. Adams, R. Kendell, E. Hare and P. Munk-Jorgensen, "Epidemiological Evidence that Maternal Influenza Contributes to the Aetiology of Schizophrenia," British Journal of Psychiatry, Vol. 163, 1993, pp. 522-534. doi:10.1192/bjp.163.4.522

[59] C. Barr, S. Mednick and P. Munk-Jorgensen, "Exposure to Influenza Epidemics during Gestation and Adult Schizophrenia," Archives of General Psychiatry, Vol. 47, No. 9, 1990, pp. 869-874.

[60] I. Jones and D. Frei, "Seasonal Births in Schizophrenia," Acta Psychiatrica Scandinavica, Vol. 59, 1979, pp. 164-172. doi:10.1111/j.1600-0447.1979.tb06958.x

[61] R. Kendell and W. Adams, "Unexplained Fluctuations in the Risk for Schizophrenia by Month and Year of Birth," British Journal of Psychiatry, Vol. 158, 1991, pp. 758-763.

[62] H. Kunugi, S. Nanko, N. Takei, K. Saito, N. Hayashi and H. Kazamatsuri, "Schizophrenia Following in utero Exposure to the 1957 Influenza Epidemics in Japan," American Journal of Psychiatry, Vol. 152, No. 3, 1995, pp. 450-452.

[63] F. Limosin, F. Rouillon, C. Payan, J. M. Cohen and N. Strub, "Prenatal Exposure to Influenza as a Risk Factor for Adult Schizophrenia," Acta Psychiatrica Scandinavica, Vol. 107, 2003, pp. 331-335. doi:10.1034/j.1600-0447.2003.00052.x

[64] J. McGrath and D. Castle, "Does Influenza Cause Schizophrenia? A Five Year Review," Australian and New Zealand Journal of Psychiatry, Vol. 29, No. 1, 1995, pp. 23-31. doi:10.3109/00048679509075888

[65] S. Mednick, R. Machon and M. Huttunen, "An Update on the Helsinki Influenza Project," Archives of General Psychiatry, Vol. 47, No. 3, 1990, p. 292.

[66] V. Morgan, D. Castle, A. Page, S. Fazio, L. Gurrin, P. Burton, P. Montgomery and A. Jablensky, "Influenza Epidemics and Incidence of Schizophrenia, Affective Disorders and Mental Retardation in Western Australia: No Evidence of a Major Effect,” Schizophrenia Research, Vol. 26, No. 1, 1997, pp. 25-39.

[67] E. O’Callaghan, T. Gibson, H. Colohan, D. Walshe, P. Buckley, C. Larking and J. Waddington, "Season of Birth in Schizophrenia,” British Journal of Psychiatry, Vol. 158, 1991, pp. 764-769.

[68] J. Suvisaari, J. Haukka, A. Tanskanen, T. Hovi and J. Lonnqvist, "Association between Prenatal Exposure to Poliovirus Infection and Adult Schizophrenia,” American 
Journal of Psychiatry, Vol. 156, No. 7, 1999, pp. 1100-1102.

[69] N. Takei and R. Murray, "Prenatal Influenza and Schizophrenia,” British Journal of Psychiatry, Vol. 165, 1994, p. 833. doi:10.1192/bjp.165.6.833

[70] Y. Battle, B. Martin, J. Dorfman and L. Miller, "Seasonality and Infectious Disease in Schizophrenia: The Birth Hypothesis Revisited," Journal of Psychiatric Practice, Vol. 33, 1999, pp. 501-509.

[71] M. Cahill, D. Chant, J. Welham and J. McGrath, "No Significance Association between Prenatal Exposure to Poliovirus and Psychosis,” Australian and New Zealand Journal of Psychiatry, Vol. 36, 2002, pp. 373-375.

[72] L. Erlenmeyer-Kimling, Z. Folnegovic, V. Hrabak-Zerjavic, B. Borcic, V. Folnegovic-Smalc and E. Susser, "Schizophrenia and Prenatal Exposure to the 1957 A2 Influenza Epidemic in Croatia," American Journal of Psychiatry, Vol. 151, No. 10, 1994, pp. 1496-1498.

[73] J. Selten, J. Slaets and R. Kahn, "Prenatal Exposure to Influenza and Schizophrenia in Surinamese and Dutch Antillean Immigrants to the Netherlands," Schizophrenia Research, Vol. 30, No. 1, 1998, pp. 101-103. doi:10.1016/S0920-9964(97)00105-9

[74] E. Susser, S. Lin, A. Brown, L. Lumey and L. Erlenmeyer-Kimling, "No Relation between Risk of Schizophrenia and Prenatal Exposure to Influenza in Holland,” American Journal of Psychiatry, Vol. 151, No. 6, 1994, pp. 922-924.

[75] T. Westergaard, P. Mortensen, C. Pedersen, J. Wohlfahrt and M. Melbye, "Exposure to Prenatal and Childhood Infections and the Risk of Schizophrenia," Archives of General Psychiatry, Vol. 56, No. 11, 1999, pp. 993-998. doi:10.1001/archpsyc.56.11.993

[76] A. Brown and E. Derkits, "Prenatal Infection and Schizophrenia: A Review of Epidemiologic and Translational Studies,” American Journal of Psychiatry, Vol. 167, No. 3, 2010, pp. 261-280.

[77] A. Hess, J. Buchmann, U. Zettl, S. Henschel, D. Schlaefke, G. Grau and R. Benecke, "Borrelia Burgdorferi Central Nervous System Infection Presenting as an Organic Schizophrenialike Disorder,” Biological Psychiatry, Vol. 45, No. 6, 1999, p. 795.

[78] M. Stoler, J. Zoldan and P. Sirota, "Schizophreniform Episode Following Measles Infection,” British Journal of Psychiatry, Vol. 150, 1987, pp. 861-862. doi:10.1192/bjp.150.6.861

[79] A. Mitchell and D. Malone, "Physical Health and Schizophrenia," Current Opinion in Psychiatry, Vol. 19, No. 4, 2006, pp. 432-437.

[80] C. Carter, "Schizophrenia Susceptibility Genes Directly Implicated in the Life Cycles of Pathogens: Cytomegalovirus, Influenza, Herpes Simplex, Rubella, and Toxoplasma Gondii,” Schizophrenia Bulletin, Vol. 35, No. 6, 2009, pp. 1163-1182.

[81] D. Vercelli, "Mechanisms of the Hygiene Hypothesis Molecular and Otherwise," Current Opinion in Immunology, Vol. 18, 2006, pp. 733-737. doi:10.1016/j.coi.2006.09.002

[82] S. Dower, "Cytokines, Virokines and the Evolution of Immunity,” Nature Immunology, Vol. 1, No. 5, 2000, pp. 367-368.

[83] N. Nathanson and G. McFadden, "Viral Virulence,” In: N. Nathanson, Ed., Viral Pathogenesis, Lippincott-Raven, Philadelphia, 1997, pp. 85-108.

[84] J. Gilmore and L. Jarskog, "Exposure to Infection and Brain Development: Cytokines in the Pathogenesis of Schizophrenia,” Schizophrenia Research, Vol. 24, 1997, pp. 365-367.

[85] J. Gilmore and L. Jarskog, "Maternal Infection, Cytokines, and Risk for Schizophrenia,” In: S. Fatemi, Ed., Neuropsychiatric Disorders and Infection, Taylor \& Francis, London, 2005, pp. 96-106.

[86] S. Zammit, P. Allebeck, C. Dalman, I. Lundberg, T. Hemmingson, M. Owen and G. Lewis, "Paternal Age and Risk for Schizophrenia,” British Journal of Psychiatry, Vol. 183, No. 5, 2003, pp. 405-408. doi:10.1192/bjp.183.5.405

[87] D. Morens, G. Folkers and A. Fauci, "The Challenge of Emerging and Re-emerging Infectious Diseases,” Nature, Vol. 430, No. 6996, 2004, pp. 242-249. doi:10.1038/nature02759

[88] S. Saha, D. Chant, J. Welham and J. McGrath, “A Systematic Review of the Prevalence of Schizophrenia," PLoS Medicine, Vol. 2, No. 5, 2005, p. e141. doi:10.1371/journal.pmed.0020141

[89] T. Y. Zhang and M. Meaney, "Epigenetics and the Environmental Regulation of the Genome and Its Function," Annual Review of Psychology, Vol. 61, 2010, pp. 439-466. doi:10.1146/annurev.psych.60.110707.163625 